\title{
Essential oils of aromatic and medicinal plants play a role in food safety
}

\author{
Marta Laranjo ${ }^{1}$ (D) | Ana M. Fernández-León ${ }^{1}$ | Ana C. Agulheiro-Santos ${ }^{1,2}$ | \\ Maria E. Potes ${ }^{1,3}$ | Miguel Elias ${ }^{1,2}$
}

${ }^{1}$ ICAAM-Instituto de Ciências Agrárias e Ambientais Mediterrânicas, IIFAInstituto de Investigação e Formação Avançada, Universidade de Évora, Pólo da Mitra, Évora, Portugal

${ }^{2}$ Departamento de Fitotecnia, Escola de Ciências e Tecnologia, Universidade de

Évora, Pólo da Mitra, Évora, Portugal

${ }^{3}$ Departamento de Medicina

Veterinária, Escola de Ciências e

Tecnologia, Universidade de Évora, Pólo da Mitra, Évora, Portugal

\section{Correspondence}

Marta Laranjo, ICAAM-Instituto de Ciências Agrárias e Ambientais Mediterrânicas, IIFA-Instituto de Investigação e Formação Avançada, Universidade de Évora, Pólo da Mitra, Ap. 94, Évora 7006-554, Portugal.

Email:mlaranjo@uevora.pt

Funding information

COMPETE, PT2020, FEDER, Grant/ Award Number: 04/SIAC/2015-SIAC 16159; Fundação para a Ciência e a Tecnologia, Grant/Award Number: UID/ AGR/00115/2019

\begin{abstract}
Essential oils (EOs) are natural substances extracted from aromatic and medicinal plants (AMPs), important in food preservation. Several studies have shown that AMPs, as well as their EOs have antimicrobial (antibacterial and antifungal) activity. Indeed, our in vitro studies have shown that oregano and thyme EOs are effective against foodborne bacteria, isolated from fermented meat products and cheeses, such as Escherichia coli, Listeria monocytogenes, Salmonella spp., and Staphylococcus aureus. However, EOs of thyme and oregano seem to control the growth of fungi, namely Botrytis cinerea and Aspergillus spp., affecting the shelf-life of fruits during postharvest. The EOs of sage and rosemary have shown little or no antimicrobial activity. Shelf-life extension studies using several EOs (cinnamon, clove, oregano, rosemary, sage, and thyme) and AMPs were performed using pork meat, goat cheese, strawberries, and table grapes. Preliminary results regarding food safety and sensory acceptability are discussed.
\end{abstract}

\section{Practical applications}

Consumers' demands for more traditional and healthier food products led to a search for alternatives to replace synthetic by natural additives. EOs of AMPs contribute to food safety, due to their antimicrobial properties. Consequently, the use of AMPs' EOs may also extend the shelf-life of food products. In the present study, experimental shelf-life trials using EOs with different food products were performed, with promising preliminary results. Cinnamon, sage, and thyme EOs extended the shelflife of strawberries and table grapes. Oregano EO prolonged the shelf-life of soft cheese. Thyme EO controlled the population of enterobacteria present in pork meat. Furthermore, the conditions used in this study can be directly applied in the food industry. Moreover, AMPs may be interesting alternatives to replace or reduce artificial food additives.

\section{1 | INTRODUCTION}

The European Union (EU) defines aromatic and medicinal plants (AMPs) as plants which are used first and foremost for their aromatic or medicinal properties in pharmacy or perfumery (Lubbe \& Verpoorte, 2011). They are aromatic plants because they produce and exude aromatic substances used in making perfumes, in cooking, and in the food, pharmaceutical, and liquor industries. These plants have the ability to synthesize a wide variety of chemical compounds used to perform important biological functions, and to defend against attack from predators, such as insects, fungi, and herbivorous mammals. 
AMPs have been used in our gastronomy since ancient times, but the potential application of their essential oils (EOs) in foods has only been more recently reported (Burt, 2004). Nevertheless, EOs of AMPs have been shown to play a role in food safety (Gyawali \& Ibrahim, 2014; Laranjo, Fernández-Léon, Potes, Agulheiro-Santos, \& Elias, 2017).

Several authors have reviewed the use of AMPs EOs, and reported both their antibacterial as well as their antifungal in vitro activities (Burt, 2004; Kloucek et al., 2012; Reyes-Jurado, FrancoVega, Ramírez-Corona, Palou, \& López-Malo, 2014; Swamy, Akhtar, \& Sinniah, 2016).

Several studies have reported the use of AMPs or their EOs on traditional Mediterranean foods, such as fruits (Campos et al., 2016; Sivakumar \& Bautista-Baños, 2014), cheeses (Asensio, Grosso, \& Rodolfo Juliani, 2015; Es'haghi Gorji et al., 2014; Govaris, Botsoglou, Sergelidis, \& Chatzopoulou, 2011; Olmedo, Nepote, \& Grosso, 2013; Smith-Palmer, Stewart, \& Fyfe, 2001), and meat and meat products (Aminzare, Hashemi, Hassanzad Azar, \& Hejazi, 2016), namely pork meat (D'Amato et al., 2016), chicken breast meat (Fratianni et al., 2010), dry-cured sausages (García-Díez, Alheiro, Falco, Fraqueza, \& Patarata, 2017; García-Díez et al., 2016) and lamb meat (Karabagias, Badeka, \& Kontominas, 2011).

The present study evaluated the in vitro antimicrobial activity of AMPs EOs, and further investigated the role of AMPs and their EOs in shelf-life studies, through the evaluation both microbiological quality and sensory acceptability of food products by trained panelists.

\section{MATERIALS AND METHODS}

\section{1 | In vitro studies}

Food grade commercial EOs from six AMPs, namely cinnamon (Cinnamomum verum former Cinnamomum zeylanicum), clove (Syzygium aromaticum former Eugenia caryophyllus), oregano (Oreganum vulgare), rosemary (Rosmarinus officinalis), sage (Salvia sclarea), and thyme (Thymus vulgaris) were used.

The in vitro antimicrobial activity of these commercial pure EOs (Plena Natura, Portugal; and PharmaPlant, Portugal) against bacteria isolated from cheeses, and meat products, namely dry-cured pork sausages, and fungi isolated from fruits, namely strawberries, and table grapes, was evaluated.

The antibacterial activity was classified in three categories according to Espina and co-workers (2011).

The antifungal activity was measured as percentage (\%) of growth inhibition after 12 days incubation at $25^{\circ} \mathrm{C}$ (Duarte et al., 2013) and results were recorded as percentage of inhibition according to Álvarez, Delgado, Salazar, and Hurtado (2010).

\section{2 | Shelf-life studies}

For shelf-life studies, the results of in vitro studies as well as preliminary tests were performed to optimize which EOs and in which concentrations to use, as described previously (Arvind, Agarwal, \& Vishnuraj, 2015).

An impregnated cotton gauze $\left(25 \mathrm{~cm}^{2}\right)$ containing the EO (diluted 1:10 in food grade ethanol) was put inside $\mathrm{PPET}$ (recycled polyethylene terephthalate) boxes $(190 \times 115 \times 90 \mathrm{~mm})$ containing either strawberries or table grapes (approximately 500 g; Campos et al., 2016).

Following preliminary trials, strawberries were subjected to two different treatments (sage and thyme), while seedless table grapes ("Crimson") were subjected to three treatments (cinnamon, sage, and thyme). Both cases were compared with controls (with no treatment). Fruits were stored in a cold chamber at $2^{\circ} \mathrm{C}$ with a relative humidity of $95 \%$. The postharvest behavior was evaluated for 12 days for strawberries, and 42 days for table grapes.

Soft goat cheese was manufactured in a local cheese industry. Three treatments were studied and compared to control: oregano EO $(0.34 \mathrm{mg} / \mathrm{g}$ of cheese formulation), oregano dry leaves $(10 \mathrm{~g} / \mathrm{kg}$ of cheese formulation, according to artisanal manufacturing practice), and both. Oregano EO as well as oregano dry leaves was used as ingredients in cheese production. Cheese samples were stored for 8 days at $5^{\circ} \mathrm{C}$.

The shelf-life of fresh pork meat treated with oregano and thyme EOs was evaluated by putting an impregnated cotton gauze $\left(25 \mathrm{~cm}^{2}\right)$ containing the $\mathrm{EO}$ (diluted 1:10 in water) on the inner surface of meat rPET boxes $(230 \times 115 \times 100 \mathrm{~mm})$.

The following microbiological parameters were analyzed according to international standard methods: total mesophilic bacteria ISO 4833 (2013), psychrotrophic bacteria ISO 17410 (2001), enterobacteria ISO 21528 (2017), yeasts and moulds ISO 21527 (2008). The results were expressed in log cfu/g.

Different panels of 10 qualified judges for fruits, cheeses, and meat were trained in accordance with ISO 8586 (1993). Sensory evaluation was carried out in a sensory laboratory designed in accordance with ISO 8589 (2007). A descriptive quantitative method was adopted, using a structured scale ranging from 0 (no sensation perceived) to 100 (maximum sensation perceived), with different attributes considered for each food product.

Three batches, and two replicates per batch, were analyzed for all shelf-life studies. Results were analyzed according to One-Way ANOVA using Statistica TM v.7.0, software from Statsoft (StatSoft Inc, Palo Alto, CA, USA, 1984-2007). Significant differences ( $p<.05)$ were identified based on Tukey Honest Significant Difference (HSD) test.

\section{3 | RESULTS}

\section{1 | In vitro studies}

Oregano and thyme EOs are effective against foodborne bacteria, isolated from fermented meat products and cheeses, such as Escherichia coli, Listeria monocytogenes, Salmonella spp., and Staphylococcus aureus (Table 1). Rosemary and sage show low or no antimicrobial activity, while cinnamon and clove show intermediate antimicrobial activity against all tested bacteria. 
TAB LE 1 Antimicrobial activity of EOs measured by the inhibition halo diameter (in $\mathrm{mm}$ ) against gram-negative and gram-positive bacteria

\begin{tabular}{|c|c|c|c|c|}
\hline EOs & \multicolumn{2}{|c|}{ Gram-negative bacteria } & \multicolumn{2}{|l|}{ Gram-positive bacteria } \\
\hline Cinnamon & $14.7 \pm 0.6(\mathrm{M})$ & $14.7 \pm 0.6(\mathrm{M})$ & $15.7 \pm 0.6(\mathrm{M})$ & $13.7 \pm 0.6(\mathrm{M})$ \\
\hline Clove & $15.5 \pm 0.5(\mathrm{M})$ & $13.5 \pm 0.5(\mathrm{M})$ & $15.0 \pm 1(\mathrm{M})$ & $13.3 \pm 0.6(\mathrm{M})$ \\
\hline Oregano & $26.5 \pm 0.5(\mathrm{~S})$ & $24.5 \pm 0.5(\mathrm{~S})$ & $32.5 \pm 0.5(\mathrm{~S})$ & $37.0 \pm 1(S)$ \\
\hline Rosemary & $6.0 \pm 0.0(\mathrm{NI})$ & $6.0 \pm 0.0(\mathrm{NI})$ & $15.5 \pm 0.5(\mathrm{M})$ & $8.5 \pm 0.5(\mathrm{NI})$ \\
\hline Thyme & $26.8 \pm 0.8(S)$ & $26.3 \pm 0.6(S)$ & $29.5 \pm 0.5(\mathrm{~S})$ & $25.7 \pm 0.6(\mathrm{~S})$ \\
\hline
\end{tabular}

Notes: Values are presented as mean $(\mathrm{mm}) \pm S D(n=3)$.

Abbreviations: $\mathrm{M}$, moderate antimicrobial activity $(10-20 \mathrm{~mm})$; NI, no antimicrobial activity $(<10 \mathrm{~mm})$; S, strong antimicrobial activity $(>20 \mathrm{~mm})$. Inhibition haloes include the disk diameter (6 mm).

EO of thyme (Table 2) is the most effective one and seems to control the growth of all studied fungal isolates. Oregano EO, however, inhibited the growth of Aspergillus spp., Alternaria sp., Botrytis cinerea, Cladosporium sp., and Penicillium sp. The EOs of sage and rosemary have shown little or no antimicrobial activity, while cinnamon and clove EOs showed an intermediate antimicrobial activity (Table 2).

\subsection{Shelf-life studies with fruits}

The number of non-marketable strawberries was evaluated every 3 days. Strawberries may be considered non-marketable either due to the presence of fungi or due to other causes of decay (e.g., presence of worms, weight loss, and fruit softening; Campos et al., 2016). The predominant fungus isolated from strawberries was Botrytis cinerea.

Until Day 6, only a few losses were observed, and all were caused by the presence of fungi. On the ninth day, the number of non-marketable strawberries increased pronouncedly, particularly in the control treatment. Sage EO showed the best results controlling fungi, mainly Botrytis cinerea and Rhizopus spp. Thyme EO has been reported as being very effective controlling $B$. cinerea and Penicillium expansum in some apple cultivars (Lopez-Reyes, Spadaro, Gullino, \& Garibaldi, 2010). However, in the trial with strawberries, we did not observe the expected results regarding the control of $B$. cinerea by thyme EO (Campos et al., 2016).

Microbiological analyses throughout 42 days (data not shown) revealed that moulds were the predominant microbiota present in table grapes, with Aspergillus niger being isolated from most samples. Psychrotrophic and mesophilic bacteria were present in slightly lower numbers (approximately 2.0 log after 42 days), while enterobacteria were mostly not detected.

Cinnamon, sage, and thyme EOs were effective in controlling the population of moulds until Day 21. A significant reduction (approximately $2.5 \log$ to $1.0-1.5 \mathrm{log}$ ) was observed on the seventh day (Figure 1).
Cinnamon was the most effective EO on Days 28 and 35, although on Day 28 it was not significantly different from the control treatment $(p>.05)$ (Figure 1). Cinnamon EO treated samples were not evaluated on Day 42, due to a pronounced browning of the rachis (visual inspection). Melgarejo-Flores et al. (2013) investigated the effect of vapors of cinnamon leaf oil on table grapes stored at $10^{\circ} \mathrm{C}$ for 15 days among other methods (emulsions, and coatings). They observed that the cinnamon oil vapor was the most effective in reducing fungal decay and maintaining the antioxidant activity of grapes, without affecting its acceptability by consumers due to the odor of the oil.

Furthermore, vapors of EOs were able to decrease the dehydration process and consequently the weight loss in "Crimson Seedless" (Valverde et al., 2005) and "Autumn Royal" table grapes (Valero et al., 2006), thus hindering the beginning of the fungal infection process, by maintaining the integrity of grapes' skin.

EOs seem to play a major role in delaying the onset of fungi rather than inhibiting fungal growth. It is possible that their action is fungistatic and not fungicidal. Generally, the use of EOs in the preservation of strawberries and table grapes did not depreciate the sensory quality of fruits, as evaluated by the panelists (data not shown). This statement is in accordance with the conclusion of Ponce, Roura, Valle, and Moreira (2008) that referred that the application of EOs volatiles should not affect fruit aromas produced by volatiles, such as esters, alcohols, ketones, sesquiterpenes, and aldehydes. Nevertheless, the use of high concentrations of EOs could cause negative effects on flavor.

\section{3 | Shelf-life studies with soft goat cheese}

All microbiological groups increased their counts in goat's cheese from 0 (TO) to 8 (T8) days of storage (Figure 2). The combined treatment of oregano leaves and oregano EO was the most effective in controlling all microbial groups, although with no significant differences $(p>.05)$. 
No significant differences were observed in the numbers of all tested microbial groups between the sixth (T6) and eighth day (T8) for the treatment with oregano EO and oregano leaves $(p>.05)$ : mesophiles (7.2-7.3 log cfu/g), psychrotrophic bacteria (7.5-7.5 log $\mathrm{cfu} / \mathrm{g})$, enterobacteria (7.2-7.3 log $\mathrm{cfu} / \mathrm{g})$, and yeasts (4.7-4.9 log $\mathrm{cfu} / \mathrm{g})$.

Sensory evaluation evidenced the rejection of the soft goat cheeses treated with oregano in all forms, due to the presence of a pronounced bitter taste (data not shown). However, the cheeses manufactured only with oregano leaves were highly appreciated (data not shown).

\section{4 | Shelf-life studies with pork meat}

The population of all studied microbial groups increased from Day 0 to Day 6 (Figure 3).

Results with oregano EO in meat revealed no significant reduction in the populations of the studied microbial groups $(p>.05)$. However, thyme EO showed some promising results in reducing the counts of all studied microbial groups, particularly enterobacteria $(p<.05)$.

A few random sensory analyses indicate that the use of EOs does not depreciate pork meat organoleptic attributes. Moreover, their presence was noticed and positively appreciated by the panelists (data not shown).

\section{4 | DISCUSSION}

The use of different AMPs and their EOs was determined taking into account their in vitro antimicrobial activity. Furthermore, EOs were also selected depending on the food product, according to the use of these aromatic "herbs" in the traditional Mediterranean diet.

One of the main causes of postharvest losses in fruits is the presence of fungi, such as Botrytis cinerea, Rhizopus spp., Penicillium spp., and Aspergillus spp., among others. Particularly, strawberries have a rapidly decreasing quality during postharvest storage, and a consequently very short shelf-life, due to the losses caused by fungi. The use of cinnamon, sage, and thyme EOs in the preservation of strawberries and table grapes controlled fungal growth, thus enabling the extension of shelf-life. These results are in agreement with the ones reported before for strawberries (Campos et al., 2016).

The usual shelf-life of soft goat cheese given by the manufacture is 6 days. The use of the combined treatment of oregano and oregano EO enabled the extension of the shelf-life to 8 days, since no significant changes were observed in the microbiota of cheeses. Other authors had obtained better antibacterial results with oregano EO in feta cheese (Govaris et al., 2011).

Thyme EO was effective in controlling the population of enterobacteria present in pork meat, which was expected taking into account its in vitro antibacterial activity against gram-negative bacteria. Furthermore, several other studies have reported the use of thyme and oregano EOs, among other to preserve different meats 
FIGURE 1 Moulds (log cfu/g) present in table grapes subjected to different treatments for a postharvest period of 42 days

FIGURE 2 Microbiota (log cfu/g) of soft goat cheese with different treatments throughout shelf-life. E, enterobacteria; M, mesophiles; PB, psychrotrophic bacteria; T0, Day 0; T8, Day 8; Y, yeasts
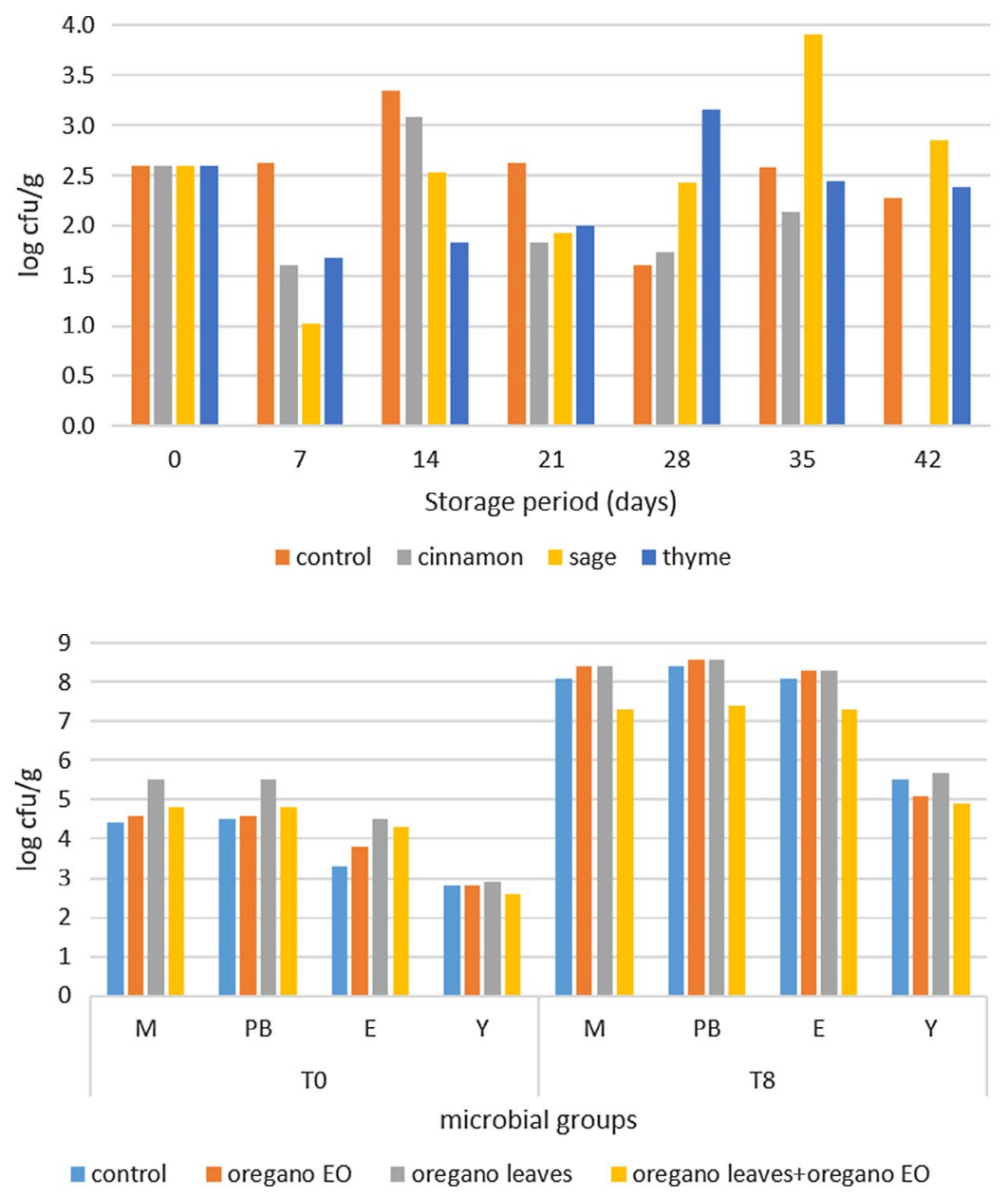

n control $\square$ oregano EO $\square$ oregano leaves $\square$ oregano leaves+oregano EO

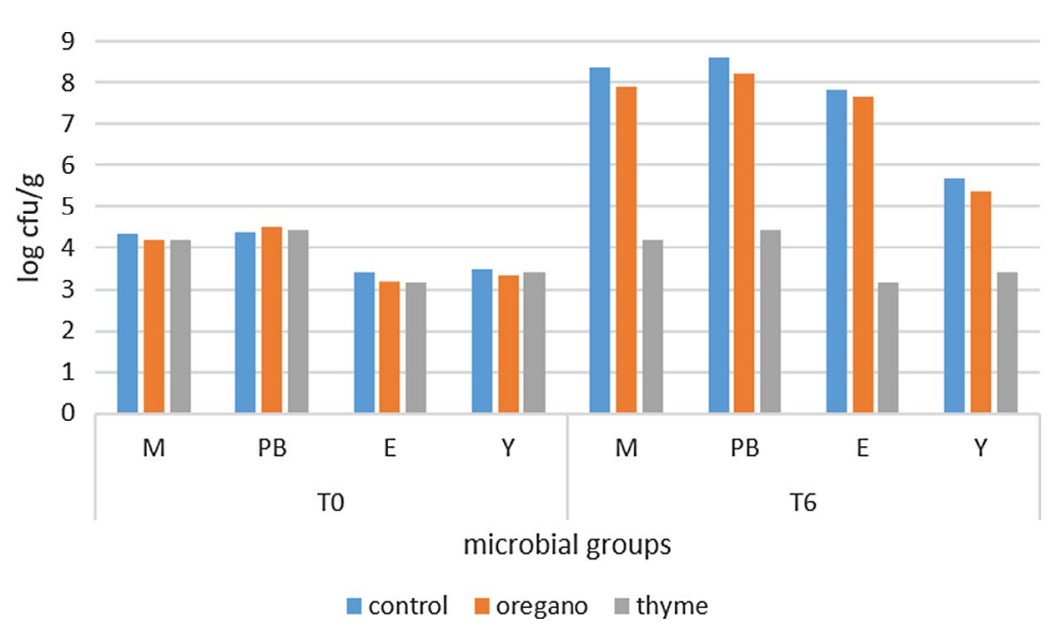

FIGURE 3 Microbiota (log cfu/g) of pork meat with different treatments throughout shelf-life. E, enterobacteria; $\mathrm{M}$, mesophiles; PB, psychrotrophic bacteria; T0, Day 0; T6, Day 6; Y, yeasts and meat products (Sharma, Mendiratta, Agarwal, Kumar, \& Soni, 2017; Soni et al., 2018; Soni, Kandeepan, Mendiratta, Shukla, \& Kumar, 2016; Thakur, Mendiratta, Chauhan, Soni, \& Agrawal, 2019).

\section{5 | CONCLUSIONS}

Promising results were obtained regarding the in vitro antimicrobial activity of oregano and thyme EOs.
The use of AMPs EOs in the preservation of different food products further needs to consider the properties of the different EOs, as well as the specific characteristics of each food matrix.

The use of EOs posed different problems in the sensory analysis, which need to be overcome, such as the perception of a pronounced bitter taste in oregano EO.

Nevertheless, AMPs and their EOs may play an important role as Generally Recognized As Safe (GRAS) alternatives to food additives, such as salt, with the purpose of extending the products' shelf-life. 


\section{ACKNOWLEDGMENTS}

This work was supported by national funds through project +AgroQualificação organizacional, energética e de segurança e saúde no trabalho da indústria agroalimentar (04/SIAC/2015-SIAC 16159) and Fundação para a Ciência e a Tecnologia (FCT) under project UID/ AGR/00115/2019.

\section{CONFLICT OF INTEREST}

The authors have declared no conflicts of interest for this article.

\section{ORCID}

Marta Laranjo (D) https://orcid.org/0000-0002-3900-5592

Miguel Elias (D) https://orcid.org/0000-0002-0877-0101

\section{REFERENCES}

Álvarez, D., Delgado, D., Salazar, C., \& Hurtado, A. (2010). Evaluación de la sensibilidad del patógeno Phytophthora infestans (Mont.) de Bary al bioinsumo de fique (Furcraea gigantea Vent) in vitro. Paper presented at the Memorias XII Congreso Internacional/XXXVII Nacional de la Sociedad Mexicana de Fitopatología, Mérida, México.

Aminzare, M., Hashemi, M., Hassanzad Azar, H., \& Hejazi, J. (2016). The use of herbal extracts and essential oils as a potential antimicrobial in meat and meat products: A review. Journal of Human, Environment, and Health Promotion, 1(2), 63-74. https://doi.org/10.29252/ jhehp.1.2.63

Arvind, G. K., Agarwal, R., \& Vishnuraj, M. R. (2015). Antimicrobial effect of oregano and thyme essential oils coated carrageenan based edible film. Journal of Pure and Applied Microbiology, 9(2), 1657-1663.

Asensio, C. M., Grosso, N. R., \& Rodolfo Juliani, H. (2015). Quality preservation of organic cottage cheese using oregano essential oils. LWT - Food Science and Technology, 60(2), 664-671. https://doi. org/10.1016/j.lwt.2014.10.054

Burt, S. (2004). Essential oils: Their antibacterial properties and potential applications in foods: A review. International Journal of Food Microbiology, 94(3), 223-253. https://doi.org/10.1016/j.ijfoo dmicro.2004.03.022

Campos, T., Barreto, S., Queirós, R., Ricardo-Rodrigues, S., Félix, M. R., Laranjo, M., ... Agulheiro-Santos, A. C. (2016). Conservação de morangos com utilização de óleos essenciais. AGROTEC, 18, 90-96.

D'Amato, S., Mazzarrino, G., Rossi, C., Serio, A., López, C. C., Celano, G. V., \& Paparella, A. (2016). Thymus vulgaris (red thyme) and Caryophyllus aromaticus (Clove) essential oils to control spoilage microorganisms in pork under modified atmosphere. Italian Journal of Food Safety, 5(3), 5785. https://doi.org/10.4081/ijfs.2016.5785

Duarte, Y., Pino, O., Infante, D., Sánchez, Y., Travieso, M. D. C., \&Martínez, B. (2013). Efecto in vitro de aceites esenciales sobre Alternaria solani Sorauer. Revista de Protección Vegetal, 28, 54-59.

Es'haghi Gorji, M., Noori, N., Nabizadeh Nodehi, R., Jahed Khaniki, G., Rastkari, N., \& Alimohammadi, M. (2014). The evaluation of Zataria multiflora Boiss. essential oil effect on biogenic amines formation and microbiological profile in Gouda cheese. Letters in Applied Microbiology, 59(6), 621-630. https://doi.org/10.1111/lam.12319

Espina, L., Somolinos, M., Lorán, S., Conchello, P., García, D., \& Pagán, R. (2011). Chemical composition of commercial citrus fruit essential oils and evaluation of their antimicrobial activity acting alone or in combined processes. Food Control, 22(6), 896-902. https://doi. org/10.1016/j.foodcont.2010.11.021
Fratianni, F., De Martino, L., Melone, A., De Feo, V., Coppola, R., \& Nazzaro, F. (2010). Preservation of Chicken breast meat treated with thyme and balm essential oils. Journal of Food Science, 75(8), M528-M535. https://doi.org/10.1111/j.1750-3841.2010.01791.x

García-Díez, J., Alheiro, J., Falco, V., Fraqueza, M. J., \& Patarata, L. (2017). Chemical characterization and antimicrobial properties of herbs and spices essential oils against pathogens and spoilage bacteria associated to dry-cured meat products. Journal of Essential Oil Research, 29(2), 117-125. https://doi.org/10.1080/10412905.2016.1212738

García-Díez, J., Alheiro, J., Pinto, A. L., Soares, L., Falco, V., Fraqueza, M. J., \& Patarata, L. (2016). Behaviour of food-borne pathogens on dry cured sausage manufactured with herbs and spices essential oils and their sensorial acceptability. Food Control, 59, 262-270. https://doi. org/10.1016/j.foodcont.2015.05.027

Govaris, A., Botsoglou, E., Sergelidis, D., \& Chatzopoulou, P. S. (2011). Antibacterial activity of oregano and thyme essential oils against Listeria monocytogenes and Escherichia coli O157:H7 in feta cheese packaged under modified atmosphere. LWT - Food Science and Technology, 44(4), 1240-1244. https://doi.org/10.1016/j.Iwt.2010.09.022

Gyawali, R., \& Ibrahim, S. A. (2014). Natural products as antimicrobial agents. Food Control, 46, 412-429. https://doi.org/10.1016/j.foodc ont.2014.05.047

ISO 8586-1. (1993). Sensory analysis-General guidance for the selection, training and monitoring of assessors-Part 1: Selected assessors.

ISO 17410 C.F.R. (2001). Microbiology of food and animal feeding stuffs-Horizontal method for the enumeration of psychrotrophic microorganisms.

ISO 8589. (2007). Sensory analysis-General guidance for the design of test rooms.

ISO 21527-2 C.F.R. (2008). Microbiology of food and animal feeding stuffs-Horizontal method for the enumeration of yeasts and moulds-Part 2: Colony count technique in products with water activity less than or equal to 0,95 .

ISO 4833-1 C.F.R. (2013). Microbiology of the food chain-Horizontal method for the enumeration of microorganisms-Part 1: Colony count at 30 degrees $C$ by the pour plate technique.

ISO 21528-2 C.F.R. (2017). Microbiology of the food chain-Horizontal method for the detection and enumeration of EnterobacteriaceaePart 2: Colony-count technique.

Karabagias, I., Badeka, A., \& Kontominas, M. G. (2011). Shelf life extension of lamb meat using thyme or oregano essential oils and modified atmosphere packaging. Meat Science, 88(1), 109-116. https://doi. org/10.1016/j.meatsci.2010.12.010

Kloucek, P., Smid, J., Frankova, A., Kokoska, L., Valterova, I., \& Pavela, R. (2012). Fast screening method for assessment of antimicrobial activity of essential oils in vapor phase. Food Research International, 47(2), 161-165. https://doi.org/10.1016/j.foodres.2011.04.044

Laranjo, M., Fernández-Léon, A. M., Potes, M. E., Agulheiro-Santos, A. C., \& Elias, M. (2017). Use of essential oils in food preservation. In A. Méndez-Vilas (Ed.), Antimicrobial research: Novel bioknowledge and educational programs (pp. 177-188). Badajoz, Spain: Formatex Research Center.

Lopez-Reyes, J. G., Spadaro, D., Gullino, M. L., \& Garibaldi, A. (2010). Efficacy of plant essential oils on postharvest control of rot caused by fungi on four cultivars of apples in vivo. Flavour and Fragrance Journal, 25(3), 171-177. https://doi.org/10.1002/ffj.1989

Lubbe, A., \& Verpoorte, R. (2011). Cultivation of medicinal and aromatic plants for specialty industrial materials. Industrial Crops and Products, 34(1), 785-801. https://doi.org/10.1016/j.indcrop.2011.01.019

Melgarejo-Flores, B. G., Ortega-Ramírez, L. A., Silva-Espinoza, B. A., González-Aguilar, G. A., Miranda, M. R. A., \& Ayala-Zavala, J. F. (2013). Antifungal protection and antioxidant enhancement of table grapes treated with emulsions, vapors, and coatings of cinnamon leaf oil. Postharvest Biology and Technology, 86, 321-328. https://doi. org/10.1016/j.postharvbio.2013.07.027 
Olmedo, R. H., Nepote, V., \& Grosso, N. R. (2013). Preservation of sensory and chemical properties in flavoured cheese prepared with cream cheese base using oregano and rosemary essential oils. LWT - Food Science and Technology, 53(2), 409-417. https://doi.org/10.1016/j. Iwt.2013.04.007

Ponce, A. G., Roura, S. I., del Valle, C. E., \& Moreira, M. R. (2008). Antimicrobial and antioxidant activities of edible coatings enriched with natural plant extracts: In vitro and in vivo studies. Postharvest Biology and Technology, 49(2), 294-300. https://doi.org/10.1016/j. postharvbio.2008.02.013

Reyes-Jurado, F., Franco-Vega, A., Ramírez-Corona, N., Palou, E., \& López-Malo, A. (2014). Essential oils: Antimicrobial activities, extraction methods, and their modeling. Food Engineering Reviews, 7(3), 275-297. https://doi.org/10.1007/s12393-014-9099-2

Sharma, H., Mendiratta, S. K., Agarwal, R. K., Kumar, S., \& Soni, A. (2017). Evaluation of anti-oxidant and anti-microbial activity of various essential oils in fresh chicken sausages. Journal of Food Science and Technology, 54(2), 279-292. https://doi.org/10.1007/s13197-016-2461-z

Sivakumar, D., \& Bautista-Baños, S. (2014). A review on the use of essential oils for postharvest decay control and maintenance of fruit quality during storage. Crop Protection, 64, 27-37. https://doi. org/10.1016/j.cropro.2014.05.012

Smith-Palmer, A., Stewart, J., \& Fyfe, L. (2001). The potential application of plant essential oils as natural food preservatives in soft cheese. Food Microbiology, 18(4), 463-470. https://doi.org/10.1006/ fmic.2001.0415

Soni, A., Gurunathan, K., Mendiratta, S. K., Talukder, S., Jaiswal, R. K., \& Sharma, H. (2018). Effect of essential oils incorporated edible film on quality and storage stability of chicken patties at refrigeration temperature $\left(4 \pm 1^{\circ} \mathrm{C}\right)$. Journal of Food Science and Technology, 55(9), 3538-3546. https://doi.org/10.1007/s13197-018-3279-7

Soni, A., Kandeepan, G., Mendiratta, S. K., Shukla, V., \& Kumar, A. (2016). Development and characterization of essential oils incorporated carrageenan based edible film for packaging of chicken patties.
Nutrition \& Food Science, 46(1), 82-95. https://doi.org/10.1108/ nfs-05-2015-0065

Swamy, M. K., Akhtar, M. S., \& Sinniah, U. R. (2016). Antimicrobial properties of plant essential oils against human pathogens and their mode of action: An updated review. Evidence-Based Complementary and Alternative Medicine: Ecam, 2016, 1-21. https:// doi.org/10.1155/2016/3012462

Thakur, N., Mendiratta, S. K., Chauhan, G., Soni, A., \& Agrawal, R. K. (2019). Antioxidant and antimicrobial effect of oregano essential oil on shelf-life of chicken patties. International Journal of Current Microbiology and Applied Sciences, 8(02), 3076-3087. https://doi. org/10.20546/ijcmas.2019.802.360

Valero, D., Valverde, J. M., Martínez-Romero, D., Guillén, F., Castillo, S., \& Serrano, M. (2006). The combination of modified atmosphere packaging with eugenol or thymol to maintain quality, safety and functional properties of table grapes. Postharvest Biology and Technology, 41(3), 317-327. https://doi.org/10.1016/j.posth arvbio.2006.04.011

Valverde, J. M., Guillén, F., Martínez-Romero, D., Castillo, S., Serrano, M., \& Valero, D. (2005). Improvement of table grapes quality and safety by the combination of modified atmosphere packaging (MAP) and eugenol, menthol, or thymol. Journal of Agricultural and Food Chemistry, 53(19), 7458-7464. https://doi.org/10.1021/jf050 $913 \mathrm{i}$

How to cite this article: Laranjo M, Fernández-León AM, Agulheiro-Santos AC, Potes ME, Elias M. Essential oils of aromatic and medicinal plants play a role in food safety. J Food Process Preserv. 2019;00:e14278. https://doi. org/10.1111/jfpp.14278 